\title{
ADAPTATION TO MODERATE Altitude HYPOXEMIA: THE EXAMPLE OF THE VALLEY OF MEXICO
}

\author{
José R. PÉREZ-PADILLA*
}

Department of Research on Smoking and COPD, Instituto Nacional de Enfermedades Respiratorias Ismael Cosío Villegas, SSA, Mexico City, Mexico

\begin{abstract}
A large world population resides at moderate altitude. In the Valley of Mexico (2,240 m above sea level), its inhabitants, breathe approximately $29 \%$ more on average and have $10 \%$ increased hemoglobin concentrations compared to sea level residents, among other differences. These compensations reduce but not eliminate the impact of altitude hypoxemia. The objective of the manuscript is to review and describe the information available on health and disease at moderate altitudes, mainly with data in Spanish language from Latin-American countries. Young adults in Mexico City have an $\mathrm{SaO}_{2}$ between $92 \%$ and $94 \%$ versus $97 \%$ at sea level, frequently decreasing below $90 \%$ during sleep and intense exercise. It is likely that among the population living at this altitude, lung growth, and development during pregnancy and infancy are enhanced, and that after residing for several tens of thousands of years, more important adaptations in oxygen transport and utilization have developed, but we are not certain about it. For patients with respiratory diseases, residing at moderate altitudes implies increased hypoxemia and clinical deterioration, unless supplementary oxygen is prescribed or patients move to sea level. Hyperventilation increases exposure of residents to air pollutants compared to those living in cities with similar concentrations of pollutants, although at sea level. Humans evolved at sea level and lack the best-known adaptations to reside at moderate or high altitudes. Residents of moderate altitudes breathe deeply the city's air with all its pollutants, and more often require supplementary oxygen. (REV INVEST CLIN. 2022;74(1):4-15)
\end{abstract}

Keywords: Moderate altitude. Hypoxemia. Acclimatization. Adaptation. Valley of Mexico.

\section{INTRODUCTION}

The risks of residing or visiting sites at a high altitude above sea level (usually considered if $>2,500 \mathrm{~m}$ ) and derived hypoxemia were gradually discovered throughout history, although most of what is known about adaptation to altitude was discovered in the first half of the $20^{\text {th }}$ century. The most relevant research focused on populations that live permanently at $>3,500 \mathrm{~m}$ above sea level and on diseases due to exposure to high altitudes, generically called "mountain sickness," with information obtained during ascents or in laboratory simulations with hypobaric oxygen chambers. In the great elevations, however,
*Corresponding author:

José R. Pérez-Padilla

E-mail: perezpad@unam.mx
Received for publication: 22-03-2021

Approved for publication: 28-07-2021

DOI: $10.24875 / R I C .21000159$

0034-8376 / (c) 2021 Revista de Investigación Clínica. Published by Permanyer. This is an open access article under the CC BY-NC-ND license (http://creativecommons.org/licenses/by-nc-nd/4.0/). 
scarce and unique populations live permanently, concentrated primarily in the Andean and Himalayan zones. Most of the research at extreme altitudes was done because of the implications for mountaineering and to explore physiological adaptations to extreme conditions. Two of the most well-known projects were in fact called Operation Everest, although they studied volunteers from several altitudes. The study of these populations described the responses of humans to high altitude, although extreme, and allowed to compare them with those of other species. However, it is also important to learn about the behavior of populations that live at moderate altitudes (2,000$2,800 \mathrm{~m}$ ), where a large number of people live in several countries in the world, especially in Latin America.

The objective of the present review is therefore, to describe responses found in populations that live at moderate altitudes, using mainly reported data from Mexico City and the Valley of Mexico (2,240 m above sea level), but also information from other Latin American cities. In the Valley of Mexico, research on altitude has been conducted since the colonial era and more formally in the $19^{\text {th }}$ and early $20^{\text {th }}$ centuries, mainly by Daniel Vergara Lope, prompted in part by observations and conclusions of Dennis Jourdanet ${ }^{1}$. Vergara Lope flatly rejected an expression of Jourdanet, which disdained the possible adaptation to hypoxemia of the population of the Valley of Mexico and considered it irreversibly affected by its consequences. In fact, exposure to moderate altitude with physical activity may have health benefits for some patients ${ }^{2}$. Relevant investigators in Latin America also studied in the mid-20 $0^{\text {th }}$ century the adaptation to altitudes ${ }^{3-5}$, centering mainly in populations residing at high altitude.

The focus of this review is primarily on aspects relevant to respiratory and cardiovascular responses, although other important aspects such as the impact on prenatal development, reproduction, sports training, and neuropsychological functions ${ }^{6}$ are not included here, as well as the basic mechanisms that trigger hypoxemia and its response, among others, all deserving detailed summaries. The effect on respiratory diseases is also not dealt with, although a recent review was published ${ }^{7}$ dealing mainly with the impact on asthma, COPD, pulmonary hypertension and sleep apnea. The Supplementary Annex contains a short list of general texts on high-altitude medicine and physiology, including the book edited by Hornbein and Schoene with more than 3,000 references.

\section{Search procedure}

To gather the information, we searched publications in PubMed with the following keywords: altitude, arterial blood gases, hypoxemia, combined with Mexico, City of Mexico, and moderate altitude. Furthermore, information was searched in Google's scholar, in web pages in Spanish, with the equivalent terms, to find articles primarily of Latin American origin published in local or regional journals that are not incorporated into PubMed. Research conducted at these elevations is scarce but indicates an impact of altitude on its inhabitants, and it is certainly partial on purpose, because it is based primarily on information published in Latin America.

\section{IMPACT OF ALTITUDE}

The atmosphere maintains an oxygen concentration close to $21 \%$ and does not vary with altitude throughout the whole inhabited and visited areas of the world. The main effect of altitude is the reduction of the barometric pressure (Pbar) and of the partial pressure of oxygen $\left(\mathrm{PO}_{2}\right)$ of the air and therefore, of the concentration of oxygen molecules per liter of air (molar concentration of oxygen). For example, in relation to sea level, the Pbar in Mexico City (585 Torr or $\mathrm{mmHg}$ on average) is $77 \%$ that of sea level ( 760 Torr), and the $\mathrm{PO}_{2}$ of the inspired air $\left(\mathrm{P}_{1} \mathrm{O}_{2}\right)$, the air, hot and humid in the trachea, is 113 Torr, $75 \%$ of 150 Torr at sea level.

The limit for a permanent residence of humans is considered an altitude of $5-5.5 \mathrm{~km}$, where the Pbar is reduced to about $50 \%$ of that at sea level (more precisely, at an altitude of $5.8 \mathrm{~km}$, Pbar falls to half of the pressure at sea level). Above this altitude, there is only temporary human presence either for work - in general mostly during the day, and sleeping in lower places - or for mountaineering. The other absolute limit has been the ascent to Everest without oxygen, a feat that can be performed by very few humans, and on favorable days when the Pbar is higher than average. 


\section{WORLD POPULATION LIVING AT MODERATE ALTITUDES}

The population that permanently lives in sites of moderate altitude is substantial in the world and in Latin America, especially in countries such as Peru and Bolivia $^{8}$. It is estimated that around 140 million people live in the world at altitudes higher than $2,500 \mathrm{~m}$ above sea level ${ }^{9}$, including $25 \%$ of Peruvians, and $4.5 \%$ of Mexicans. In Mexico, $50 \%$ of the population lives at altitudes higher than $1,500 \mathrm{~m}^{10}$. The cities of Mexico, Puebla, and Tlaxcala, with altitudes of around 2,200 m, Zacatecas and Pachuca 2,400 m, and Toluca 2,650 $\mathrm{m}$, are examples of cities at moderate altitude where large populations are concentrated ${ }^{11,12}$.

\section{MECHANISMS OF PHYSIOLOGIC RESPONSES TO HYPOXEMIA}

Briefly, the responses to hypoxemia are triggered by activation of the oxygen sensor, a protein encoded by the EGLN1 gene, which increases the hypoxia-inducible factors (HIF1A, HIF2A, and HIF3A). These transcription factors, when they accumulate, induce the transcription of hundreds of genes, which, in turn, trigger the various bodily responses to hypoxia: increase in gas exchange, erythropoiesis (through erythropoietin), neovascularization by angiogenic growth and tissue remodeling factors, activation of genes related to glucose metabolism, changes related to vasomotor and endothelial control, and alterations in the functioning of the carotid body. These responses have a time course that can take from minutes to generations. The fastest responses are called acclimatization, typically occurring when a native of sea level travels to higher altitudes, and are generally reversible on returning to sea level; examples are hyperventilation and increased hemoglobin $(\mathrm{Hb})$ concentration. There are non-reversible changes of development in people who were born and live at altitude; and finally, there are changes that occur by natural selection in thousands to hundreds of thousands of years. Most responses to hypoxemia are triggered when $\mathrm{SaO}_{2}$ decreases to below $90 \%$.

Genetic variants of the oxygen sensor have been demonstrated, the hypoxia-inducible factors and gene transcriptions being more frequent in the more ancient populations residing at altitude, the Tibetan and Peruvian, compared to those at sea level. The Tibetan pattern has sustained the hyperventilation of acclimatization permanently (without decreasing with age), but has blocked polycythemia, with opposite changes in the Peruvian population due to variants of the genes related to the oxygen sensor and the transcription factors. Evolutionary changes can be expected primarily in populations that have inhabited high areas for several tens of thousands of years, present, for example, in Asian populations of Tibet and Nepal.

On the other hand, in the Valley of Mexico, in Tlapacoya, human remains have been found with an estimated age of 12,000 years $^{13}$, along with obsidian objects and animal bones dated between 22,000 and 25,000 years ${ }^{14}$. According to experts' opinions, these findings can suggest human presence for a long time before the dated ages ${ }^{15}$, not different from those found at altitude in the Himalayas ${ }^{16}$. It is important to note that the mechanisms of adaptation to altitude vary between Tibetans, Ethiopians and Peruvians $^{17}$, the three being effective since they have populations that live permanently and reproduce at similar altitudes. However, the Tibetan form of adaptation appears to have advantages, because they have $\mathrm{Hb}$ concentrations similar to those at sea level and higher alveolar ventilations. Of great interest is the high frequency of the gene EPAS1 (which encodes HIF2alpha) related to $\mathrm{Hb}$, traditionally low in the population of the Himalayas and postulated to originate from the Denisovan hominid race ${ }^{18,19}$, which was increasing in the population presumably because of exposure to altitude. Previously, high frequencies of the EGLN1 and PPARA genes had been identified in a hypoxemic population, and which could provide adaptive benefits ${ }^{20}$.

\section{ACCLIMATIZATION TO ALTITUDE}

When a person travels to a place at a higher altitude than his or her residence, a process called acclimatization occurs beginning in the $1^{\text {st }}$ days after arrival, with rapid responses such as hyperventilation. In fact, one of the most efficient compensations is the increase in the number and especially in the depth of breaths. Hyperventilation occurs gradually in hours but usually persists for decades in residents of a considerable altitude. The loss of hyperventilation at advanced ages has been described in some South American 
Figure 1. Lower graph: Reported hemoglobin according to altitude in several regions of South-America (mostly in Peru, from Hurtado et al.) and those from Ruiz-Arguelles et al. study from Mexico. Upper graph: Mean pulmonary artery pressure at rest measured at different altitudes in America including Denver and Leadville, Colorado. Rises more consistently above sea level values around $2000 \mathrm{~m}$.

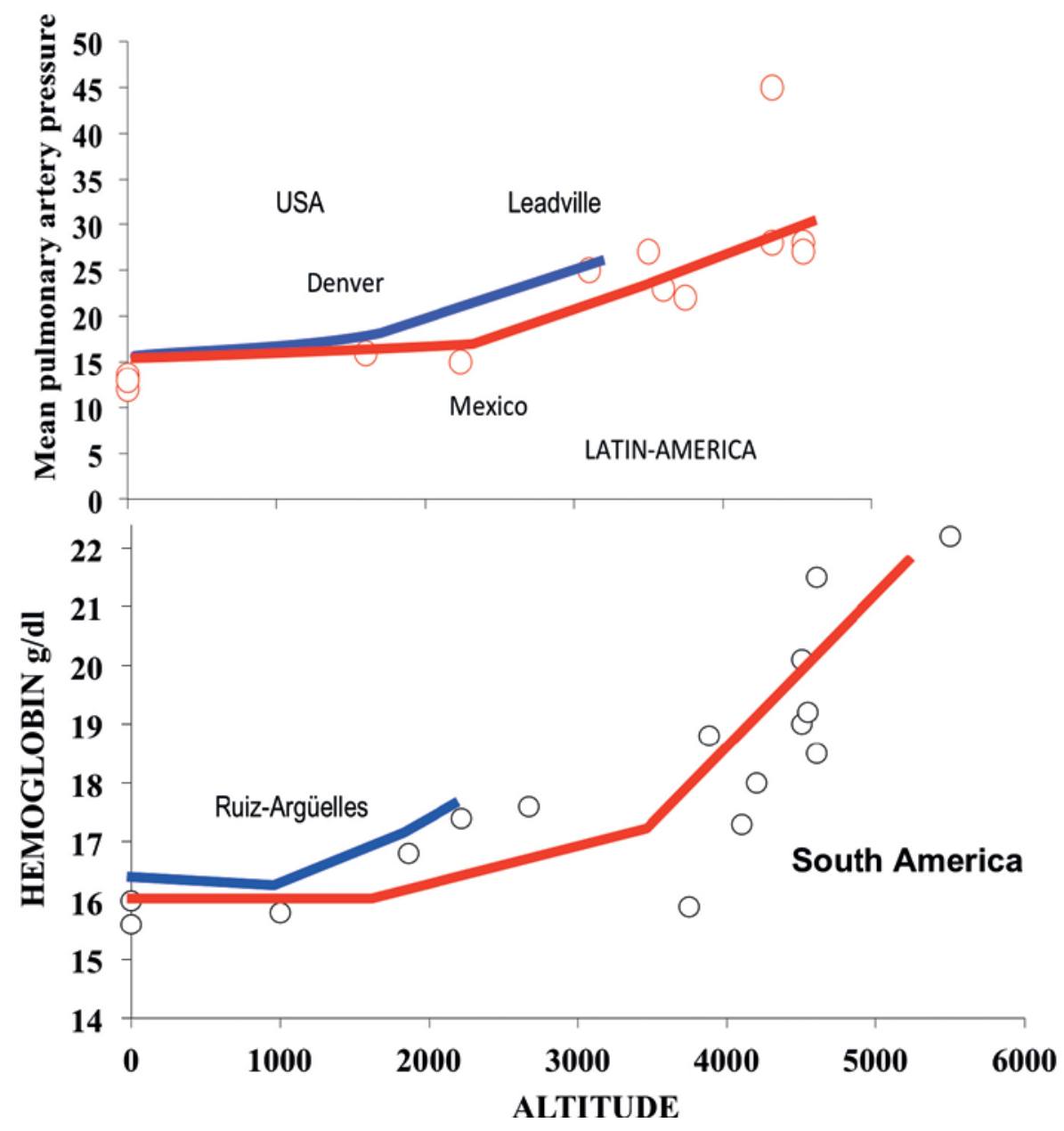

populations, manifested by an increase in the partial pressure of carbon dioxide in the arterial blood $\left(\mathrm{PaCO}_{2}\right)$ in middle-aged adults ${ }^{4,5}$.

Another frequent compensation, which develops in weeks, is the increase in the production of red blood cells and in the concentration of $\mathrm{Hb}$ in the blood (polycythemia), triggered by the production of erythropoietin, resulting in an increase in the transport capacity of oxygen in the blood (Fig. 1, lower graph). This increase in $\mathrm{Hb}$, unlike hyperventilation, affects $\mathrm{PaO}_{2}$ very little, but tends to improve the concentration of oxygen in venous blood. Therefore, an improvement in tissue oxygenation up to a certain point is expected, where an increase in blood viscosity slows microcirculation.
With time, profound tissue changes are generated, which involve vascularization (shorter distance from the tissue to the capillary, with improved diffusion), and adjustments in the enzymes related to the production of energy, with optimization of oxidative processes and energy production.

Alveolar hypoxia leads to pulmonary vasoconstriction, a very efficient mechanism to compensate local or regional lung diseases, shifting the flow to ventilated acini, as occurs in pneumonia, likely the commonest cause of hypoxemia. However, altitude hypoxia leads to diffuse vasoconstriction and increase in pulmonary resistance that may generate pulmonary artery hypertension during exercise or even at rest (Fig. 1, upper graph). The degree of hypoxic 
Figure 2. Olympic marks in long-distance running competition from 1948 to 1976. A continuous reduction in times is observed (expressed as percentage of 1952 Olympic Games), except for the Mexico City Olympics in 1968.

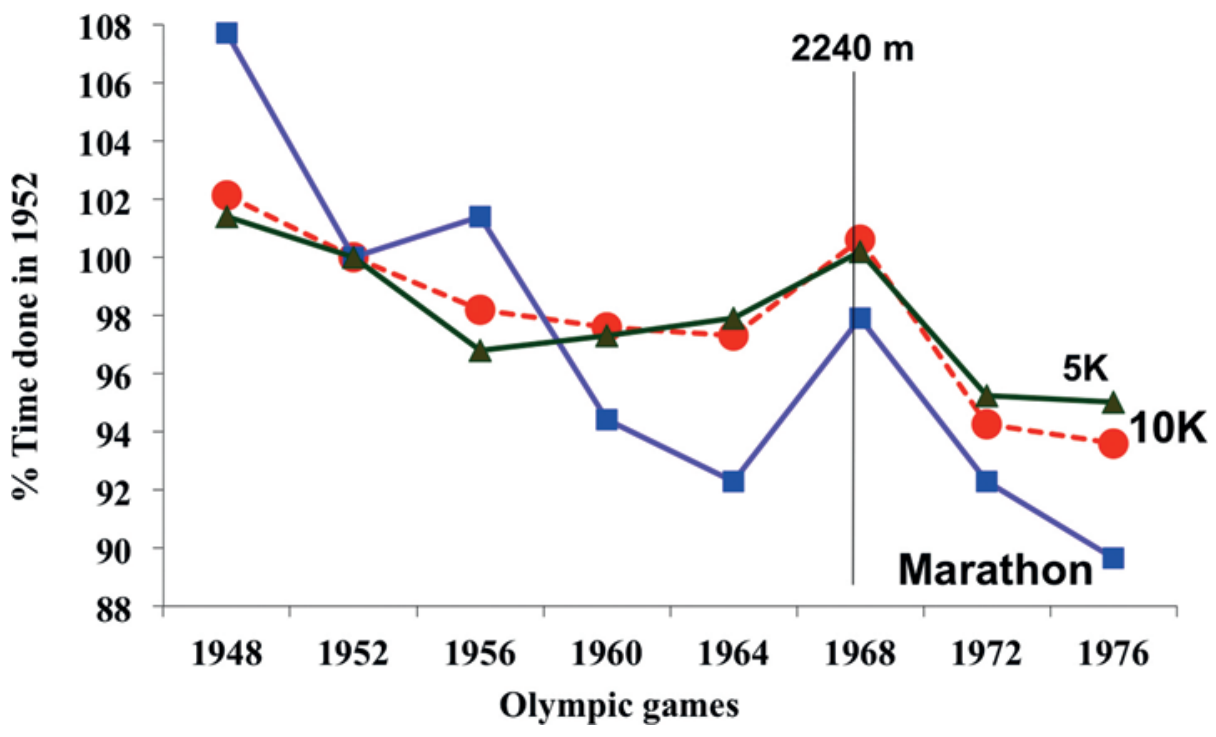

vasoconstriction is considered heterogeneous in the population, and these variations may explain an improved or worsened tolerance to altitude in shortterm or long-term exposures, and in general, to illnesses associated with high altitude. Pulmonary artery pressure in normal subjects varies among individuals, and according to genetic ancestry. Pulmonary hypertension is expected to be more common among Aymara than among Tibetans at the same altitude, and was reported as normal in Mexico City among healthy subjects ${ }^{21}$.

\section{ADAPTIVE CHARACTERISTICS IN THE RESIDENT POPULATION OF THE VALLEY OF MEXICO}

Table 1 lists several characteristics found in the resident population at moderate altitudes, such as the Valley of Mexico, which are generally known manifestations of altitude adaptation.

\section{Oxygenation level}

Table 2 compares the typical arterial blood gases' values at sea level, and those found in Mexico City as a result of a compilation of $\mathrm{PaCO}_{2}$ values (which show an average of 31 Torr in arterial blood) and $\mathrm{PaO}_{2}$ (on average 65 , although it decreases with age) reported in healthy subjects ${ }^{22}$, with a mean $\mathrm{SaO}_{2}$ between $92 \%$ and $94 \%$. On the other hand, a mean $\mathrm{pH}$ of 7.4 (with its range of values) and the appropriate base excess for the $\mathrm{pH}$ of 7.4 (the normal value for Mexico City is a mean of $-5 \mathrm{mEq} / \mathrm{L}$ ), have been traditionally considered normal. $\mathrm{PaO}_{2}$ values fall with age (between 0.25 and 0.3 Torr or $\mathrm{mmHg}$ per year) and with increasing weight, among other factors ${ }^{23}$. $\mathrm{PaCO}_{2}$ remains more constant throughout life, although an increase in $\mathrm{PaCO}_{2}$ with age, especially in postmenopausal women, has been described ${ }^{24}$.

In Mexico, a compilation of published studies has been frequently used as a reference, which in general has been adequate and concludes at an average $\mathrm{PaCO}_{2}$ of 31 Torr $^{22}$. This $\mathrm{PaCO}_{2}$ level implies that the residents of Mexico ventilate (alveolar ventilation) 29\% more than people living at sea level, which although substantially improves oxygenation, it increases the basal respiratory work and work at any exercise level. Hyperventilation facilitates the generation of dyspnea, a complex feeling that occurs consistently when minute ventilation or respiratory work is close to the individual's maximum, especially relevant for respiratory patients.

On the adverse side, there is also a greater exposure to pollutants (at the same atmospheric concentration; see section on environmental pollution) and, in 
Table 1. Adaptive changes to altitude and hypoxemia in population of the Valley of Mexico

\begin{tabular}{llc}
\hline Mechanism & \multicolumn{1}{c}{ Data } & Reference \\
\hline Chronic hyperventilation & Mexico $\mathrm{PaCO}_{2}$ 31 Torr (mmHg) & 22 \\
& Bogotá 33 Torr & 36 \\
Polycythemia & Hemoglobin about 10\% higher than at sea level & 45 \\
$\begin{array}{l}\text { Exercise capacity, maximal }{ }_{2} \\
\text { consumption }\end{array}$ & Reduced in sea-level athletes competing in Mexico & 35 \\
$\begin{array}{l}\text { Ventilatory responses to hypoxemia } \\
\text { and } \mathrm{CO}_{2}\end{array}$ & $\begin{array}{l}\text { Often flat to hypoxemia (precise percentage unknown) } \\
\text { Pulmonary artery pressure }\end{array}$ & and normal response (slope) to CO 2 \\
Spirometric values & Normal in healthy subjects & 21 \\
& Higher than Mexican-Americans at sea level if adjusted & 41 \\
DL & by height, age and gender. Could be an effect of & 43 \\
Maximal voluntary ventilation & stunting as occurs in underserved areas. \\
and Peak expiratory flow rate & Higher than at sea level even after adjustment & 42 \\
\hline
\end{tabular}

*We lack information about muscle adaptations as well as vascularization, or glycolysis enzymes or genetic variants linked to Amerindian ancestry, or frequency of genes associated with adaptation to altitude in Tibetan or Peruvian populations.

Table 2. Normal values at sea level and at 2,240 m above sea level (Mexico City)

\begin{tabular}{|c|c|c|}
\hline Variable & Sea level & $\begin{array}{c}2,240 \mathrm{~m} \\
\text { (Mexico City) }\end{array}$ \\
\hline Mean Pbar (Torr) & 760 & 585 \\
\hline $\mathrm{PaO}_{2}$ (Torr)* & $80-100$ & $65-70$ \\
\hline $\mathrm{PaCO}_{2}$ (Torr) & $40 \pm 2$ & $31 \pm 2$ \\
\hline $\mathrm{pH}$ & $7.35-7.45$ & $7.35-7.45$ \\
\hline $\mathrm{HCO}_{3}-(\mathrm{mEq} / \mathrm{L})$ & $24 \pm 3$ & $19 \pm 3$ \\
\hline Base Excess (mEq/L) & 0 & -5 \\
\hline $\mathrm{SaO}_{2}(\%)$ & $97 \%$ & $92-94 \%$ \\
\hline $\begin{array}{l}\text { Hemoglobin } \\
\text { (g/dL, men and women) }\end{array}$ & $16 \pm 2,14 \pm 2$ & $17.4 \pm 0.9,14.6 \pm 1$ \\
\hline Hematocrit (\%) & $47 \pm 5,42 \pm 5$ & $51.6 \pm 2.6,44.6 \pm 2.7$ \\
\hline $\mathrm{P}(\mathrm{A}-\mathrm{a}) \mathrm{O}_{2}$ (Torr) & $<15$ (about age/3) & $<15$ (age/3) \\
\hline Mean Pap (Torr) & $<16$ & $<16$ \\
\hline
\end{tabular}

${ }^{*} \mathrm{PaO}_{2}$ declines with age (approximately 0.3 Torr or $\mathrm{mmHg}$ per year) and in decubitus; see text. For hemoglobin and hematocrit is mean and standard deviation. Shunt in both altitudes is $<5 \%$ of the cardiac output in healthy subjects. Chlorine should increase in the same proportion as bicarbonate decreases to maintain ionic equilibrium.

Pbar: mean barometric pressure; $\mathrm{PaO}_{2}$ : partial pressure of $\mathrm{O} 2$ in the arterial blood; $\mathrm{SaO} 2$ : oxygen saturation of hemoglobin in the arterial blood; $\mathrm{P}(\mathrm{A}-\mathrm{a}) \mathrm{O}_{2}$ : alveolo-arterial difference in $\mathrm{PO}_{2}$; $\mathrm{Pap}$ : pulmonary artery pressure.

principle, a greater caloric and water loss. Chronic hypocapnia is accompanied by a loss of bicarbonate and base excess, and most probably an increase in chlorine ( $\mathrm{Cl}-$ ) for ionic balance (Table 2).

The $\mathrm{SaO}_{2}$ at rest in Mexico City, although above $90 \%$ (in healthy and young individuals), the limit below which many of the responses to hypoxemia are triggered, is near the knee of the $\mathrm{Hb}$ dissociation curve with oxygen, in a region where mild falls in $\mathrm{PaO}_{2}$, such as those that can occur during sleep ${ }^{25}$, or in decubitus, especially in obese people and with aging, cause a greater decrease in saturation. In the metropolitan area of Mexico City, $6 \%$ of the population $\geq 40$ years of age has an $\mathrm{SaO}_{2}$ of $\leq 88 \%$, which, if chronic, meets the current criteria for recommending home 
Figure 3. Lower limits of normality (5th percentile according to altitude and age, from a population-based survey in 5 cities of Latin America (PLATINO STUDY).

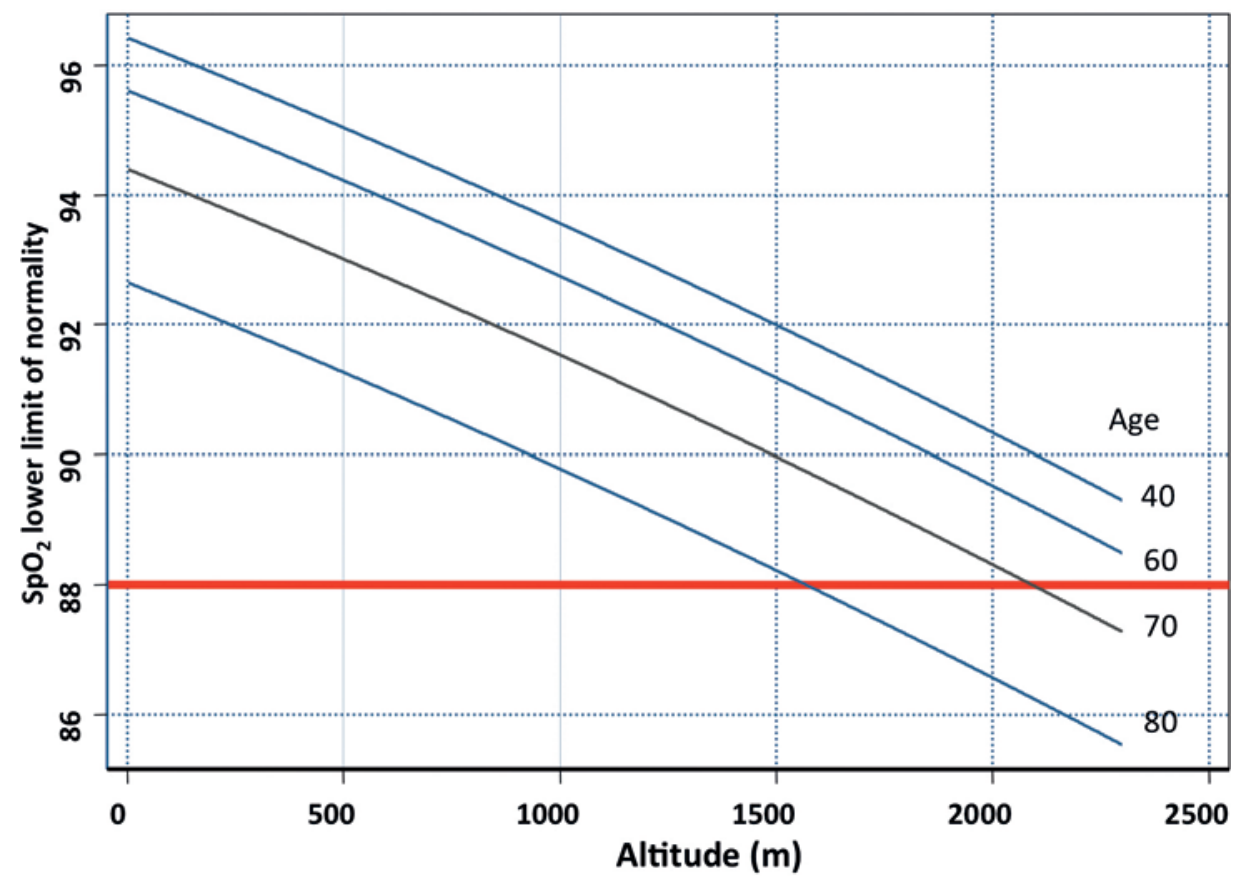

oxygen therapy ${ }^{23}$. That is, a reasonable compensation for hypoxemia can be achieved only if the entire gas exchange system works properly but there is a limited reserve.

Even with these usual levels of oxygenation, $\mathrm{SaO}_{2}$ between $92-94 \%$ (vs. $97 \%$ at sea level), responses to hypoxemia in healthy and young people are observed in Mexico City (Tables 1 and 2), which proves the need for improved indicators of hypoxemia than a point measure of arterial blood gases or pulse oximetry, measured awake and resting. Within these measures, the continuous estimation of $\mathrm{SaO}_{2}$ could be considered for prolonged periods, at least $24 \mathrm{~h}$, which allow identifying hypoxemia during sleep or exercise, undetectable for typical measurements at rest. Of more relevance would be the measurement of tissue oxygenation, general or regional, but at this moment, there are no instruments that allow to perform it in the clinical setting in a routine and noninvasive way.

With altitude, red cell 2,3 diphosphoglycerate tends to increase leading to a rightward shift of the standard oxyhemoglobin dissociation curve and $\mathrm{PO}_{2}$ at
$50 \%$ saturation ( $p 50$ ). However, the presence of respiratory alkalosis during acclimatization to simulated altitude tends to compensate the in vivo p50.

\section{ESTIMATION OF GASOMETRIC VALUES AT DIFFERENT ALTITUDES IN MEXICO}

Because it is unlikely that reference values will be generated for many altitudes in Mexico, Latin America or other countries with settlements at various altitudes, it is important to have estimates of the expected values ${ }^{10}$. Although these estimates cannot substitute for actual measurements, they can be of great help for the proper interpretation of gasometry data, instruments that are accessible in many places. These estimates based on the alveolar gas equation (Supplementary material) are available for different altitudes and populations in Mexico, and a proper estimate depends to a large extent on having an estimated $\mathrm{PaCO}_{2}$ close to the real one for altitude, based preferably on interpolation of empirical data. Other moderate-altitude reports on arterial blood gases can be found in additional publications $24,26-28$. 


\section{Oxygenation during sleep}

Healthy, young subjects residing in Mexico City frequently have an $\mathrm{SaO}_{2}<90 \%$ at night ${ }^{25}$. It is known that the sleep of visitors at high altitudes, generally above $2500 \mathrm{~m}$, is interrupted in coincidence with periodic breathing, which generates wide oscillations in oxygenation. Like other alterations frequently observed at high altitudes, it could occur ${ }^{29}$, but less frequently, at moderate altitudes in visitors who arrive from sea level. In the residents of the Valley of Mexico, periodic breathing is not a characteristic of their breathing during sleep, but the frequency among visiting lowlanders is unknown. On the other hand, respiratory patients ${ }^{30,31}$ and obese individuals ${ }^{32}$ suffer from severe hypoxemia during sleep much more frequently than at sea level, at the same degree of lung damage, which presumably worsens their prognosis unless domiciliary oxygen therapy is prescribed. In the PLATINO population study, $6 \%$ of the $40+$ year-old population in the metropolitan area of Mexico City had an $\mathrm{SaO}_{2} \leq 88 \%$, level at which oxygen should be prescribed to prevent deterioration in health and an increase in mortality, especially if additional indicators of hypoxemia are present: polycythemia, pulmonary hypertension, or hypertrophy or dilatation of the right heart. Acetazolamide may reduce altitude periodic breathing in newcomers to moderate altitude, as well as supplementary oxygen, acting as stabilizers of the breathing rhythm.

\section{RESPONSE OF THE CHEMORECEPTORS TO HYPOXIA AND HYPERCAPNIA}

The ventilatory response to hypoxemia and hypercapnia has been evaluated in residents of Mexico City ${ }^{33-}$ 35. The slope of the response to $\mathrm{CO}_{2}$ does not differ from that found at sea level, but the intercept is modified by the baseline level of $\mathrm{PaCO}_{2}$, which is lower in Mexico City than at sea level ${ }^{33}$, with a higher respiratory drive than at sea level ${ }^{34}$. That is, the change in ventilation per change in $\mathrm{PaCO}_{2}$ is similar in the Valley of Mexico to that at sea level (same slope of the response curve). On the other hand, in a minority of healthy individuals, the response found to hypoxemia was flat ${ }^{35}$. This has been previously reported in Andean areas, and its consequence is uncertain since, although it would be expected that respiratory work and periodic breathing during sleep would decrease, it could cause greater hypoxemia in the face of a lung disease or due to an ascent to higher altitudes. It would be necessary to determine how widespread this response is in the healthy population that resides at moderate altitude, and if it occurs since childhood or develops with age, or whether it is associated with the Amerindian genetic contribution.

\section{HEMATOPOYESIS}

Ruiz-Arguelles et al. studied the hematological indices at the level of the cities of Puebla and Toluca, finding a clear increase in $\mathrm{Hb}$ at the altitude of Puebla (same as that of the Valley of Mexico) and even more so in Toluca, with a borderline change at lower altitude (Fig. 1, Lower graph) ${ }^{36}$. Hb increases $5.5 \%$ in lowlanders acclimatized to $2,100 \mathrm{~m}$ and stabilizes after 7 months ${ }^{37,38}$. It is important to note that within Mexico City, there is a variation of altitudes due to land unevenness, with areas of a considerably higher altitude. For example, the main exit roads of Mexico City rise up to $3,100 \mathrm{~m}$, similar to the altitudes of Toluca (the Marquesa), Cuernavaca (Tres Marías) and Puebla (Río Frío), with settlements on these sites, as well as in the area of the Ajusco mountain (up to 3,930 $\mathrm{m})$. Therefore, individuals with higher than usual degrees of polycythemia can be seen in the city, although these values could be appropriate for the person's place of residence, an information which should always be considered for an adequate understanding of the oxygenation level of an individual. Erythropoietin increases rapidly after exposure to moderate altitudes $^{39}$, although differences have not been reported among blood donors compared to published studies at sea level ${ }^{40}$.

\section{LUNG FUNCTION AT MODERATE ALTITUDES}

Lung function and, therefore, respiratory function tests can be affected at altitude by several mechanisms. On the one hand, the ethnic composition of the population tends to change with the altitude, having in general populations with a greater indigenous component living at higher altitudes, as is the case in Peru and Mexico, among other countries. Ethnic composition can have important implications for health and disease susceptibility. Frequently, the populations at 
higher altitudes also have lower socioeconomic levels and greater degree of marginality, which considerably affects the health, anthropometric measures, and the respiratory function itself. Malnutrition and marginal conditions tend to reduce height and the proportion between the body's upper or thoracic segment and the lower or pelvic segment, so that at the same height, the proportion of chest and lungs is higher than usual. Since the prediction equations for spirometry and other tests of respiratory mechanics include height as a predictor, it has been shown that children and adults of the Valley of Mexico have consistently higher altitude-adjusted values than populations of European or Mexican-American ancestry at sea level, and considerably higher than those of African origin ${ }^{41}$.

There are respiratory tests based on maximum expiratory or inspiratory flows that involve turbulent flow, dependent on the air density, such as the peak expiratory flow rate (PEFR) and maximum voluntary ventilation (MVV). With altitude, the air density decreases and higher maximum flows can be generated, which has been demonstrated for the PEFR ${ }^{41}$ and for the $M V V^{42}$. Finally, exposure to chronic hypoxemia, from the prenatal stage and during growth and development, can affect the size of the chest and lungs, which has been shown at high altitudes, but not reliably at moderate altitudes.

The single-breath diffusing capacity of the lungs for carbon monoxide (DLCO), a gas exchange standard test, increases consistently with altitude due to both the lower partial $\mathrm{PaO}_{2}$, and the tendency of $\mathrm{Hb}$ to increase with altitude ${ }^{36}$. However, in spite of making the usual altitude and $\mathrm{Hb}$ adjustments recommended, the DLCO tends to be higher in Mexico City and Bogotá than that found at sea level ${ }^{43}$, which indicates a larger alveolo-capillary surface area for gas exchange, either by recruitment of alveolar capillary units even at rest, or by an effect on lung development.

\section{GAS EXCHANGE AT MODERATE ALTITUDES}

The behavior of gas exchange at moderate altitudes was recently analyzed by computational models of the lung ${ }^{44}$. These models allow us to estimate pulmonary performance under different controlled circumstances, a very useful situation from an educational and theoretical point of view but requiring empirical verification of the findings, which in real life are more complex since several changes occur simultaneously, and adjustments are not considered in the models. The patterns of response to changes in cardiac output, minute ventilation, base excess, shunt, ventilation/perfusion ( $\left.V^{\prime} / Q^{\prime}\right)$ heterogeneity, inspired fraction of oxygen, $\mathrm{Hb}$, or p50, estimated for Mexico City are generally parallel to those estimated for sea level displaced to the lower levels of $\mathrm{PO}_{2}$ and $\mathrm{PCO}_{2}$.

\section{EXERCISE CAPACITY}

A reduction in the maximum capacity to exercise and maximum oxygen consumption is expected in Mexico City at least during acute exposure or after a short acclimatization $^{45}$, a phenomenon observed in athletes since the Olympic Games in Mexico in 1968, where the distance runners increased their time by $5-10 \%$ in relation to times achieved at sea level (Fig. 2). There was also an increase in the times of the winners of long-distance tests, compared with those of the previous and subsequent Olympic games. The best marathon times in Mexico City are slower than those at sea level (in 2017, in men, Fikadu Kebede, 2:17:27; in women, Gladys Tejeda, 2:36:15), while the best world records, in places at low altitude, are for men (Dennis Kiputo), 2:02:57 and for women (Paula Radcliffe), $2: 15: 25$, and with a permanent tendency to drop. On the other hand, due to the lower air density, in Mexico City, speed increases during short tests, especially in cycling, so the velodrome in Mexico City was frequently used for attempting to break a velocity record.

Interpolating data derived from experiments at simulated progressive altitudes that reached up to the altitude of Everest (Everest operations), the expected drop in maximum oxygen consumption at 2,240 m altitude is $9 \%$, an amount difficult to demonstrate among inhabitants of the Valley of Mexico unless compared against themselves in experiments in compression chambers or with mixtures simulating sea level. Some studies have evaluated an exercise response in Mexico City ${ }^{46}$ and at other moderate altitudes ${ }^{47}$.

Not surprisingly, desaturation at high levels of exercise is frequent due to diffusion limitation, which at sea level has been reported only at maximum exercise in high-performance athletes. The altitude of residence 
has to be considered in the interpretation of desaturation in exercise, usually considered an indicator of interstitial lung disease, pulmonary vascular disease, or emphysema. However, at altitude, desaturation can be seen in healthy people if a high level of oxygen consumption is reached ${ }^{47}$. It is important to consider that desaturation in exercise can also be due to alveolar hypoventilation, especially in people with very abnormal pulmonary mechanics, or with muscle weakness, a situation that is not identified with the pulse oximeter but is perfectly clear with an arterial blood gas analysis showing increasing $\mathrm{PaCO}_{2}$ during exercise.

\section{ALTITUDE AND IMPACT OF ENVIRONMENTAL POLLUTION}

Pollutant concentrations in communities at moderate or high altitude vary; however, biomass smoke in rural areas may be a relevant outdoor pollutant in addition to being an ancient indoor pollutant in developing countries. Geographical location also may reduce pollutant dispersion, as occurs in the valleys of Mexico, Toluca, and Puebla, surrounded by high mountains. Chronic hyperventilation derived from residing at altitude implies greater exposure to air pollutants. The dose of pollutants, that is, the amount reaching the respiratory system (not necessarily the particles or toxins that pass into the blood or adhere to the mucous membranes), increases proportionally to hyperventilation. That is why an adjustment has been proposed to the permitted levels of pollutants recommended at sea level for places such as Mexico City ${ }^{48}$. The increase in ventilation does not have a linear relationship with Pbar, and it varies with ethnicity. At high altitudes, the Tibetan population maintains greater ventilation than the South-American Aymara, which has been considered an adaptation (not only acclimatization) more beneficial than that achieved in South America. At altitude, the reduction in the molar concentration of oxygen makes combustion more difficult, and it is easier for it to occur incompletely, generating more pollutants and carbon monoxide.

\section{RELEVANT FUTURE RESEARCH ISSUES}

There are a variety of research topics within the respiratory and cardiovascular areas that require attention and of which a tentative summary is made below.
It is important to elaborate on the ventilatory response to hypoxemia throughout growth, development and aging, and the Amerindian contribution to the response. Healthy adults residing in Mexico City often lack a significant response to hypoxemia, and it would be advisable to clarify whether it is a characteristic of the place of birth or is related to genetics, or whether tolerance develops over time. It would be recommended to determine arterial blood gases or non-invasive measurements (pulse oximetry, expired capnography, $\mathrm{PaO}_{2}$ and transcutaneous or expired $\mathrm{PaCO}_{2}$ ) in subjects at different altitudes, preferably performing ventilatory responses to hypercapnia and hypoxemia, and measurement of $\mathrm{Hb}$ and the Amerindian genetic contribution.

Another matter of interest would be to advance the understanding of the impact of altitude on mortality due to various diseases, and oxygen therapy requirements in Mexico. An additional relevant point is whether having lived for thousands of years at moderate altitudes, such as in the Valley of Mexico, confers a population further protection to hypoxemia, which would make it advisable to adjust the criteria for chronic oxygen therapy. The usual criterion to prescribe oxygen is the arterial blood gases in stable patients ( $\mathrm{PaO} 2<55$ Torr, or $<60$ Torr with cor pulmonale, polycythemia or pulmonary hypertension) and the question is whether these cut-off values, obtained at sea level and very consistent across a number of studies, apply to the population living at moderate altitude.

Elucidating the impact of altitude-induced hyperventilation on the damage conferred by highly concentrated pollutants in the large cities of several Latin American countries and where appropriate, the need to adjust permissible standards of contaminants for altitude, is of great relevance for the best protection of the health of the inhabitants.

\section{CONCLUSIONS}

The residents of Mexico City ventilate approximately a quarter more and have a concentration of $\mathrm{Hb}$ $10 \%$ higher than residents of sea level. These compensations reduce the impact of altitude hypoxemia, but do not eliminate it. Among healthy young people in Mexico, the level of oxygenation in the blood is between $92 \%$ and $94 \%$ (compared to $97 \%$ at sea 
level) (Figure 3), and in Mexico, it is more frequent to fall to $<90 \%$ while sleeping.

It is thus clear that the healthy residents of Mexico City manifest physiological responses to the lack of oxygen whose impact is little known. It is possible that pulmonary growth is stimulated during childhood, or that over many generations of residence at altitude the transport mechanisms and use of oxygen in tissues improve, although we do not know for sure. Residing at moderate altitudes provides a better tolerance to hypoxemia, at least in some circumstanc$\mathrm{es}^{49}$. For example, the inhabitants of Mexico City are more likely to reach the top of the Popocatepetl volcano $(5,426 \mathrm{~m})$ than those who attempt to reach it from sea level, protecting from the mountain sickness developed in other residents at a moderate altitude ${ }^{50}$.

On the other hand, patients with respiratory diseases living in Mexico City are more susceptible to severe deoxygenation, which worsens their condition rapidly and makes them require supplemental oxygen or move to sea level, and increases their exposure to air pollutants.

From the biological point of view, humans lack the best adaptations to live at high altitudes described in vertebrates because they evolved at low altitudes. The feat of climbing Mount Everest $(8,890 \mathrm{~m})$ without oxygen is achievable for very few elite athletes and always on the verge of damage and death. Staying at these extreme altitudes is possible only for very short periods of time and, in fact, a permanent residence at altitudes greater than 5,500 $\mathrm{m}$ is harmful. Furthermore, among the natives of altitudes higher than $3,000 \mathrm{~m}$, after years, a group develops in the absence of lung disease the so-called chronic mountain sickness or Monge's disease, characterized by cardio-respiratory failure and polycythemia and shortened life, which can be cured by traveling down to the coast or by using oxygen. For now, clearly the altitude of Mexico City results in a greater need for oxygen therapy at home, and makes us inhale deeper the city's air.

\section{SUPPLEMENTARY DATA}

Supplementary data are available at DOI: 10.24875/ RIC.21000159. These data are provided by the corresponding author and published online for the benefit of the reader. The contents of supplementary data are the sole responsibility of the authors.

\section{REFERENCES}

1. Rodriguez de Romo AC, Perez Padilla JR. The Mexican response to high altitudes in the 1890s: the case of a physician and his "Magic Mountain". Med Hist. 2003;47:493-516.

2. Schobersberger W, Leichtfried V, Mueck-Weymann M, Humpeler $\mathrm{E}$. Austrian moderate altitude studies (AMAS): benefits of exposure to moderate altitudes (1,500-2,500 m). Sleep Breath. 2010;14:201-7.

3. Hernando Ordonez J. Biology of altitude; studies on inhabitants of Bogota (2.640 m of altitude). An Univ Nacional Mayor San Marcos Facult Med. 1952;35:193-203.

4. Hurtado A, Aste-Salazar H. Arterial blood gases and acid-base balance at sea level and at high altitudes. J Appl Physiol. 1948; 1:304-25.

5. Monge C. El mal de montaña crónico en América. An Facult Med. 1953;36:544-62

6. Latshang TD, Lo Cascio CM, Stowhas AC, Grimm M, Stadelmann $\mathrm{K}$, Tesler $\mathrm{N}$, et al. Are nocturnal breathing, sleep, and cognitive performance impaired at moderate altitude $(1,630-2,590 \mathrm{~m})$ ? Sleep. 2013;36:1969-76.

7. Grissom CK, Jones BE. Respiratory health benefits and risks of living at moderate altitude. High Alt Med Biol. 2018;19:109-15.

8. Cohen JE, Small C. Hypsographic demography: the distribution of human population by altitude. Proc Natl Acad Sci U S A. 1998;95:14009-14

9. West JB, American College of Physicians, American Physiological Society. The physiologic basis of high-altitude diseases. Ann Intern Med. 2004;141:789-800.

10. Pérez-Padilla R. Population distribution residing at different altitudes: implications for hypoxemia. Arch Med Res. 2002;33:162-6.

11. Perez-Padilla JR. Alturas en México. Neumol Cir Torax. 1993 52:7-14.

12. Pérez Padilla JR, Vázquez García JC. Estimación de los valores gasométricos en diferentes alturas sobre el nivel del mar en México. Rev Invest Clín. 2000;52:148-55.

13. La Jornada. Restos Humanos de Más de 12 Mil Años se Exhiben en Cancún. United States: La Jornada; 2014.

14. Lorenzo JL, Mirambell L. Tlapacoya: 35,000 Años de Historia Del Lago de Chalco. Mexico: Serie Prehistórica; 1986. p. 296.

15. Wikipedia. Poblamiento de América. Wikipedia; 2018. Available from: https://www.es.wikipedia.org/wiki/Poblamiento de America. [Last accessed on 2018 Feb 04].

16. Geggel L. Tibetans Lived in Himalayas Year-round Up to 12,600 Years Ago. America: Livescience; 2017.

17. Xing G, Qualls C, Huicho L, Rivera-Ch M, Stobdan T, Slessarev $M$, et al. Adaptation and mal-adaptation to ambient hypoxia; Andean, Ethiopian and Himalayan patterns. PLoS One. 2008; 3:e2342.

18. Hackinger S, Kraaijenbrink T, Xue Y, Mezzavilla M, Asan, van Driem G, et al. Wide distribution and altitude correlation of an archaic high-altitude-adaptive EPAS1 haplotype in the Himalayas. Hum Genet. 2016;135:393-402.

19. Hu H, Petousi N, Glusman G, Yu Y, Bohlender R, Tashi T, et al. Evolutionary history of Tibetans inferred from whole-genome sequencing. PLoS Genet. 2017;13:e1006675.

20. Simonson TS, Huff CD, Witherspoon DJ, Prchal JT, Jorde LB. Adaptive genetic changes related to haemoglobin concentration in native high-altitude Tibetans. Exp Physiol. 2015;100:1263-8.

21. De Micheli A, Villacis E, Guzzydela Mora P, Rubio Alvarez V. Observations on the hemodynamic and respiratory measurements obtained in normal subjects. Arch Inst Cardiol Mex. 1960:30:507-20.

22. Pérez Martínez SO, Pérez-Padilla JR. Gasometric values reported in healthy subjects from the Mexican population: review and analysis. Rev Invest Clin. 1992;44:353-62.

23. Perez-Padilla R, Torre-Bouscoulet L, Muino A, Marquez MN, Lopez MV, de Oca MM, et al. Prevalence of oxygen desaturation and use of oxygen at home in adults at sea level and at moderate altitude. Eur Respir J. 2006;27:594-9.

24. González-García M, Maldonado D, Barrero M, Casas A, PérezPadilla R, Torres-Duque C. Arterial blood gases and ventilation at rest by age and sex in an adult Andean population resident at high altitude. Eur J Appl Physiol. 2020;120:2729-36. 
25. Hernández-Zenteno RJ, Pérez-Padilla R, Vázquez JC. Normal breathing during sleep at an altitude of 2240 meters. Arch Med Res. 2002;33:489-94.

26. Pereira-Victorio CJ, Huamanquispe-Quintana J, CasteloTamayo LE. Gasometría arterial en adultos clínicamente sanos a 3350 metros de altitud. Rev Per Med Exper Salud Públic. 2014;31:473-9.

27. Veloz AP, Barrezueta CP. Valores de Referencia de Gasometría Arterial en Población Adulta Entre 18 y 40 Años de Edad, Residente a 2800 m Sobre el Nivel Del Mar, en el Hospital Eugenio Espejo, en el Periodo de Julio a Octubre Del 2016. Monografía en la Internet. Quito: Universidad Central del Ecuador; 2016. Available from: http://www.dspace.uce.edu.ee/handle/25000/11417.

28. Tinoco Solórzano A, Román Santamaría A, Charri Victorio J. Gasometría arterial en diferentes niveles de altitud en residentes adultos sanos en el Perú. Horizonte Méd. 2017;17:6-10.

29. Yaron M, Lindgren K, Halbower AC, Weissberg M, Reite M, Niermeyer S. Sleep disturbance after rapid ascent to moderate altitude among infants and preverbal young children. High Alt Med Biol. 2004;5:314-20.

30. Vázquez JC, Pérez-Padilla R. Effect of oxygen on sleep and breathing in patients with interstitial lung disease at moderate altitude. Respiration. 2001;68:584-9

31. Vázquez-García JC, Pérez-Padilla R. Breathing during sleep in patients with chronic obstructive pulmonary disease at an altitude of 2,240 meters. Rev Invest Clin. 2004;56:334-40.

32. Valencia-Flores M, Mokhlesi B, Santiago-Ayala V, Resendiz-Garcia M, Castano-Meneses A, Meza-Vargas MS, et al. Intermittent hypoxemia and sleep fragmentation: associations with daytime alertness in obese sleep apnea patients living at moderate altitude. Sleep Med. 2016;20:103-9.

33. Sandoval Zarate J, Lupi Herrera E, Fernández Bonetti $P$, Martínez $\mathrm{ML}$, Seoane M. The respiratory center in normal subjects at 2,240 meters above sea level. The ventilatory and occlusion pressure ( $\mathrm{P} 0.1$ ) responses upon $\mathrm{CO} 2$ stimulation. Arch Inst Cardiol Mex. 1984;54:345-54.

34. Sandoval J, Beltrán U, Gómez A, López R, Martínez W, Vázquez $V$, et al. Effect of chronic altitude hypoxia on the behavior of the respiratory center. Study on normal subjects living at the altitude of Mexico city (2,240 meters). Arch Inst Cardiol Mex. 1985;55:381-7.

35. Vázquez-García JC, Arellano-Vega SL, Regalado-Pineda J, PérezPadilla JR. Normal ventilatory response to hypoxia and hypercapnia at an altitude of 2240 meters. Rev Invest Clin. 1998; 50:323-9.

36. Ruiz-Arguelles GJ, Sanchez-Medal L, Loria A, Piedras J, Córdova MS. Red cell indices in normal adults residing at altitude from sea level to 2670 meters. Am J Hematol. 1980;8:265-71.

37. Brothers MD, Doan BK, Zupan MF, Wile AL, Wilber RL, Byrnes WC. Hematological and physiological adaptations following 46 weeks of moderate altitude residence. High Alt Med Biol. 2010;11:199-208.

38. Brothers MD, Wilber RL, Byrnes WC. Physical fitness and hematological changes during acclimatization to moderate altitude: A retrospective study. High Alt Med Biol. 2007;8:213-24.

39. Ashenden MJ, Gore CJ, Dobson GP, Boston TT, Parisotto R, Emslie KR, et al. Simulated moderate altitude elevates serum erythropoietin but does not increase reticulocyte production in well-trained runners. Eur J Appl Physiol. 2000;81:428-35.

40. Morales-Polanco MR, Guerrero-Rivera S, Sánchez-Valle E, Gómez-Morales E, Gordon-Barabejzyk F, Mejía-Arregui M, et al. Blood erythropoietin levels in healthy subjects studied in the valley of Mexico. Gac Med Mex. 1997;133:399-402.

41. Pérez-Padilla $R$, Regalado-Pineda ], Rojas $M$, Catalan M, Mendoza L, Rojas R, et al. Spirometric function in children of Mexico city compared to Mexican-American children. Pediatr Pulmonol. 2003;35:177-83

42. Cid-Juarez $S$, Perez-Padilla R, Torre-Bouscoulet L, Enright $P$, Gochicoa-Rangel L, Cortes-Medina D, et al. Maximum voluntary ventilation in a population residing at 2,240 meters above sea level. Resp Care. 2017:62:1588-93

43. Vázquez-García JC, Pérez-Padilla R, Casas A, Schonffeldt-Guerrero $P$, Pereira J, Vargas-Domínguez $C$, et al. Reference values for the diffusing capacity determined by the single-breath technique at different altitudes: the Latin American singlebreath diffusing capacity reference project. Resp Care. 2016; 61:1217-23

44. Pérez-Padilla R. Intercambio gaseoso a 2,240 m de altura de acuerdo a modelos computacionales de pulmón. Neumol Cir Tórax. 2018;77:19-23.

45. Wyndham $\mathrm{CH}$, Leary WP. Physiological problems expected at the Mexico city Olympic Games. S Afr Med J. 1966:40:985-7.

46. Rangel-Abundis A, Carsolio Pacheco R, Torres-Garcia C, Salgado-Escobar JL, Urrutia-Zamudio RA. Normal respiratory response to physical exercise at moderate altitude (author's transl). Rev Invest Clin. 1976;28:137-50

47. Wiseman RL, Kelly PT, Swanney MP, McNamara KP, Beckert L. Hypoxemia in healthy subjects at moderate altitude. Aviat Space Environ Med. 2013;84:22-6.

48. Bravo Alvarez H, Sosa Echeverría R, Sánchez Alvarez P, Krupa S Air quality standards for particulate matter (PM) at high altitude cities. Environ Poll. 2013;173:255-6.

49. Muza SR, Rock PB, Zupan MF, Miller JC, Thomas WR, Cymerman $A$. Residence at moderate altitude improves ventilatory response to high altitude. Aviat Space Environ Med. 2004;75 1042-8.

50. Bernardi E, Pomidori L, Cavallari D, Mandolesi G, Cogo A. Residence at moderate versus low altitude is effective at maintaining higher oxygen saturation during exercise and reducing acute mountain sickness following fast ascent to $4559 \mathrm{~m}$. Wild Environm Med. 2017;28:122-6. 